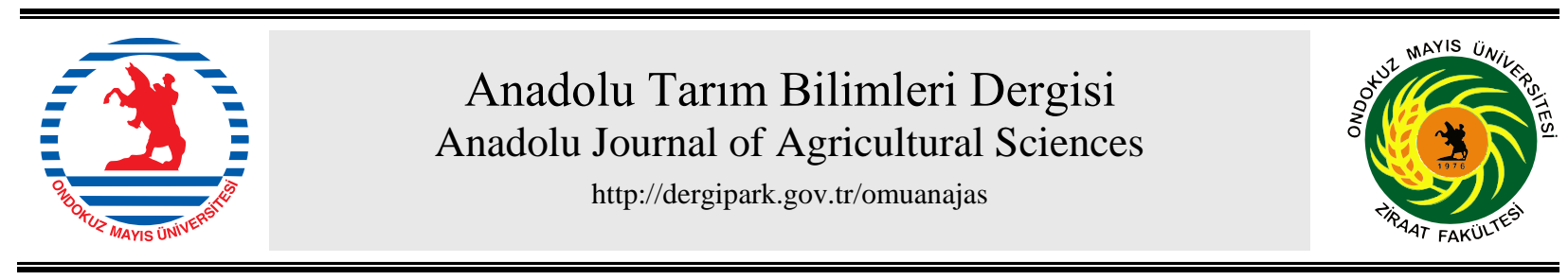

Araştırma/Research

Anadolu Tarım Bilim. Derg./Anadolu J Agr Sci, 36 (2021) ISSN: 1308-8750 (Print) 1308-8769 (Online) doi: 10.7161/omuanajas.874970

\title{
Yüksek Dormansi Grubunda Bulunan Yonca (Medicago sativa L.) Genotiplerinin Verim ve Kalite Özellikleri
}

\author{
๑Mehmet Öten ${ }^{\mathrm{a}}$, $\odot$ Sebahattin Albayrak $\mathrm{k}^{\mathrm{b}}$ \\ ${ }^{a}$ Sakarya Uygulamalı Bilimler Üniversitesi, Ziraat Fakültesi, Tarla Bitkileri Bölümü, Sakarya, Türkiye \\ ${ }^{b}$ Ondokuz Mayıs Üniversitesi, Bafra Meslek Yüksek Okulu, Bitkisel ve Hayvansal Üretim Bölümü, Samsun, Türkiye
}

*Sorumlu yazar/corresponding author: sebahattinalbayrak@omu.edu.tr

Geliş/Received 05/02/2021 Kabul/Accepted 02/05/2021

\begin{abstract}
ÖZET
Bu çalışmanın amacı non-dormant özellikteki yonca (Medicago sativa L.) genotiplerinin verim ve kalite özelliklerini belirlemektir. Araştırmada 5 adet yonca çeşidi (Fortuna, Nimet, Green star, Isinde ve Golden West) ile 1 adet çeşit adayı kullanılmıştır. Çalıșma Antalya ve Samsun olmak üzere 2 farklı lokasyonda 2018-2020 yılları arasında yürütülmüştür. Çalışma Tesadüf Blokları Deneme Desenine göre 4 tekrarlamalı olarak kurulmuş olup, her yıl Antalya'da 8 biçim, Sansun'da ise 6 biçim yapılmıştır. Araştırma sonucunda non-dormant özellikteki çeşit adayı yoncanın kuru ot verimi-3048 kg da-1, ham protein oran1-\%21.45, ADF oran1-\%29.08, NDF oran1-\%39.94, ADL oran1-\%7.36, Nispi yem değeri$\% 155$ olarak bulunmuştur. Kuru ot verimi üzerinden yapılan analiz sonuçlarına göre de aday çeşidin diğer çeşitlerden daha stabil olduğu belirlenmiştir.
\end{abstract}

Yield and Quality Characteristics of Alfalfa (Medicago sativa L.) Genotypes in the High Dormancy Group

\section{ABSTRACT}

The aim of this study was to determine the yield and quality characteristics of alfalfa (Medicago sativa L.) genotypes with non-dormant characteristics. In the study, 5 alfalfa cultivars (Fortuna, Nimet, Green star, Isınde and Golden West) and 1 cultivar candidate were used. The study was carried out in 2 different locations where Antalya and Samsun in 2018-2020. The study was established in a randomized complete block design with 4 replicates and every year 8 cuts were made in Antalya and 6 cuts in Samsun. As a result of the research, the dry matter yield of the non-dormant variety candidate alfalfa was $3048 \mathrm{~kg} \mathrm{da}^{-1}$, crude protein-21.45\%, ADF-29.08\%, NDF-39.94\%, ADL-7.36\%, Relative feed value-155\%. According to the results of the analysis made from the dry matter yield, it was determined that the candidate cultivar was more stable than the other cultivars.

Anahtar Sözcükler:

Dormansi

Kalite

Stabilite

Verim

Yonca

Keywords:

Alfalfa

Dormancy

Yield

Quality

Stability

(c) OMU ANAJAS 2021

\section{Giriş}

Yonca (Medicago sativa L.) sahip olduğu yüksek besin değerinden dolayı Dünya'da en yaygın olarak yetiştirilen çok yıllık yem bitkilerinin başında gelmektedir (Djaman ve ark. 2020). Çok geniş adaptasyon kabiliyetinin yanı sıra yüksek biyolojik azot fiksasyon kapasitesi ve yüksek kaliteli ve besleyici otunun verim değerinden dolay1 yetiştirildiği alanlar sürekli artış göstermektedir (Russele ve ark. 2007). 
Bununla birlikte farklı bölgelerde yetiştirilen yoncaların büyüme özellikleri de farklılık göstermektedir. Yoncada dormansi, gün uzunluğu ve sıcaklığın azalmasıyla birlikte sonbahar sırasında yavaşlayan büyüme olarak tanımlanır (Malinowski ve ark., 2007). Dormansi değeri bitkilerin adaptasyonu ve kışın hayatta kalabilmeleri için önemli bir rol oynamaktadir (Chen ve ark. 2014).

Yonca genotipleri, kış boyunca hayatta kalma ve yeniden büyüme yeteneklerine göre sonbaharda dormansi derecelendirmesi (FD) adı verilen 11 sınıfta gruplandırılmıştır. Dormansi gurupları: Çok dormant (FD 1, 2), dormant (FD 3, 4), az dormant (FD 5), yarı dormant (FD 6, 7), non-dormant (FD 8, 9), çok non-dormant (FD 10, 11) olarak belirtilmiştir (Djaman ve ark. 2020). Dormant çeşitler sonbaharda biçim sonrası yavaş gövde uzaması gösterdiklerinden dolayı yüksek derecede kış dayanıklılığına sahiptir. Buna karşın, dormant olmayan çeşitler sonbaharda kuvvetli bir şekilde büyür, uzun dik sürgünler oluşturur ve sonbaharda biçimden sonra hızlı sürgün uzamasına devam eder (Brummer ve ark., 2000; Dhont ve ark., 2002; Haagenson ve ark., 2003). Yonca 1slahında genotiplerin dormansi değeri seleksiyon kriteri olarak kullanılmaktadır (Fairey ve ark. 1996).

Bu çalışma, SDÜBAP-3190-D1-10 ve TUBİTAK 214 O 066 numaralı projelerden Sentetik Varyete Islah Yöntemi ile geliştirilen ve non-dormant gurupta yer alan çeşit adayı yerli yoncanın tescilli/üretim izinli yonca çeşitleri ile verim ve kalite yönünden karşılaştırılması amacıyla yürütülmüştür.

\section{Materyal ve Yöntem}

$\mathrm{Bu}$ araştırma, 2018-2020 yılları arasında, Batı Akdeniz Tarımsal Araştırma Enstitüsü'nün Antalya-Aksu'da bulunan arazisinde $\left(36^{\circ} 93^{\prime} \mathrm{K}, 30^{\circ} 89^{\prime} \mathrm{D}\right.$; rakım $\left.10 \mathrm{~m}\right)$ ve Ondokuz Mayıs Üniversitesi'nin Samsun-Bafra'da bulunan deneme alanında ( $41^{\circ} 56^{\prime} \mathrm{K}, 35^{\circ} 86^{\prime} \mathrm{D}$; rakım $15 \mathrm{~m}$ ) yürütülmüştür.

Samsun-Bafra lokasyonunda toprak bünyesi killi tınlı, toprak reaksiyonu nötr (pH: 7.03), orta derecede kireçli (\%6.5 $\left.\mathrm{CaCO}_{3}\right)$, organik maddece fakir (\%1.20), yarayışlı fosfor düzeyi orta $\left(7.5 \mathrm{~kg} \mathrm{da}^{-1} \mathrm{P}_{2} \mathrm{O}_{5}\right.$ fosfor), yarayışlı potasyumca zengin $\left(120 \mathrm{~kg} \mathrm{da}^{-1} \mathrm{~K}_{2} \mathrm{O}\right)$, toplam tuz bakımından zararsı $(\% 0.029)$ düzeydedir. Antalya-Aksu lokasyonunda ise toprak killi-tınlı bünyede, hafif alkali ( $\mathrm{pH} 7.11)$, tuzsuz (\%0.03), çok fazla kireçli (\%28.75), organik madde (\%1.82) ve yarayışlı fosfor düzeyi az $\left(2.15 \mathrm{~kg} \mathrm{da}^{-1}\right)$, potasyum yönünden ise zengindir (78.65 kg da$\left.{ }^{1}\right)$. Araştırmanın yapıldığ 1 yıllara ait iklim verileri Çizelge 1 'de verilmiştir.

Çizelge 1. Denemenin yürütüldüğü Antalya-Aksu ve Samsun-Bafra’ya ait iklim verileri Table 1. Climate data of Antalya-Aksu and Samsun-Bafra where the research were conducted

\begin{tabular}{|c|c|c|c|c|c|c|c|c|c|c|c|c|}
\hline \multirow[b]{3}{*}{ Aylar } & \multicolumn{6}{|c|}{ ANTALYA-Aksu } & \multicolumn{6}{|c|}{ SAMSUN-Bafra } \\
\hline & \multicolumn{3}{|c|}{ Yağıș $(\mathbf{m m})$} & \multicolumn{3}{|c|}{ Sıcaklık $\left({ }^{\circ} \mathrm{C}\right)$} & \multicolumn{3}{|c|}{ Yağıș $(\mathbf{m m})$} & \multicolumn{3}{|c|}{ Sicaklık $\left({ }^{\circ} \mathbf{C}\right)$} \\
\hline & $\begin{array}{l}\text { Uzun } \\
\text { Yillar }\end{array}$ & $\begin{array}{c}2018- \\
2019 \\
\end{array}$ & $\begin{array}{c}2019- \\
2020\end{array}$ & $\begin{array}{l}\text { Uzun } \\
\text { Yillar }\end{array}$ & $\begin{array}{c}2018- \\
2019 \\
\end{array}$ & $\begin{array}{c}2019- \\
2020\end{array}$ & $\begin{array}{l}\text { Uzun } \\
\text { Yillar }\end{array}$ & $\begin{array}{c}2018- \\
2019 \\
\end{array}$ & $\begin{array}{c}2019- \\
2020 \\
\end{array}$ & $\begin{array}{l}\text { Uzun } \\
\text { Yillar }\end{array}$ & $\begin{array}{c}2018- \\
2019\end{array}$ & $\begin{array}{l}2019- \\
2020 \\
\end{array}$ \\
\hline Kasım & 176.6 & 157.0 & 126.0 & 14.4 & 15.7 & 15.8 & 88.3 & 54.6 & 35.8 & 12.0 & 11.7 & 14.6 \\
\hline Aralık & 267.0 & 357.4 & 307.2 & 11.0 & 14.6 & 14.0 & 75.1 & 79.0 & 77.2 & 9.1 & 8.1 & 10.3 \\
\hline Ocak & 208.7 & 426 & 142 & 9.6 & 10.6 & 10.1 & 59.9 & 63.6 & 94.8 & 7.2 & 7.3 & 6.6 \\
\hline Şubat & 134.6 & 68.9 & 96.8 & 10.0 & 12.9 & 11.1 & 52.6 & 38.2 & 62.6 & 6.7 & 7.2 & 7.2 \\
\hline Mart & 104 & 103 & 97.2 & 12.4 & 12.7 & 12.8 & 59.4 & 30.4 & 45.2 & 7.9 & 7.7 & 10.1 \\
\hline Nisan & 62.7 & 48.0 & 50.4 & 16.0 & 15.9 & 16.3 & 54.0 & 56.8 & 27.6 & 11.1 & 11.1 & 10.1 \\
\hline Mayıs & 31.4 & 29.0 & 32.1 & 20.6 & 20.3 & 20.5 & 49.9 & 42.0 & 12.2 & 15.4 & 16.9 & 16.7 \\
\hline Haziran & 8.5 & 8.0 & 10.9 & 25.5 & 24.5 & 25.3 & 49.7 & 17.8 & 15.6 & 20.3 & 22.8 & 21.8 \\
\hline Temmuz & 2.9 & 3.0 & 4.5 & 28.5 & 28.2 & 28.4 & 32.8 & 52.2 & 0.8 & 23.5 & 22.2 & 24.4 \\
\hline Ağustos & 2.3 & 3.0 & 4.6 & 28.3 & 27.7 & 28.3 & 37.6 & 42.0 & 26.2 & 23.9 & 23.2 & 23.3 \\
\hline Eylül & 11.5 & 11.0 & 18.1 & 24.7 & 24.8 & 25.1 & 47.8 & 33.4 & 4.4 & 20.2 & 20.4 & 22.7 \\
\hline Ekim & 77.6 & 66.0 & 72.1 & 19.9 & 20.5 & 20.5 & 92.7 & 66.4 & 16.4 & 16.2 & 17.7 & 19.4 \\
\hline Toplam & 1088 & 1280 & 962 & - & - & - & 699.8 & 576.4 & 418.8 & - & - & - \\
\hline Ortalama & - & - & - & 18.4 & 19.0 & 19.0 & - & - & - & 14.5 & 14.7 & 15.6 \\
\hline
\end{tabular}

Araştırmada kontrol olarak seçilen yonca (Medicago sativa L.) çeşitleri sırasıyla Fortuna, Nimet, Green star, İsinde ve Golden West olup adı geçen tüm çeşitler yüksek dormansi ( 8 ve üzeri) grubunda yer almaktadırlar. Denemede yer alan çeşit adayı yonca ise 2010 yılında SDÜBAP-3190-D1-10 numaralı proje kapsamında; Batı Akdeniz sahil kuşağında yer alan Antalya iline ait 13 ilçede, toplam 26 farklı duraktan klon olarak toplanmış daha sonra öne çıkan genotipler TUBITAK 214 O 066 numaralı projeye aktarılmıştır. Projenin sonunda tescile sunulmadan önce bölge verim performansını belirlemek amacıyla mevcut çalışmaya dahil edilmiş olup dormansi değeri 9'dur. 
Her biçim sonrası toprak tarla kapasitesine gelinceye kadar ilk dört biçimden sonra 2 defa beşinci biçimden sonra ise 1 defa sulama yapılmıştır. Hasat sonrası alınan 500 g'lık taze ot örnekleri, kurutma dolabında 48 saat $70^{\circ} \mathrm{C}^{\prime}$ de kurutularak her bir çeşidin kuru ot verimleri (KOV) hesaplanmıştır (Albayrak ve ark., 2018).

Yonca örneklerinin ham protein oranları (HPO) (Kacar ve İnal, 2008) ADF, NDF ve ADL içerikleri ise ANKOM 220 Fiber Analyser cihazı yardımıyla ANKOM teknolojinin bildirdiği esaslara göre belirlenmiştir (Anonim, 2021). Nispi yem değerleri (NYD) Albayrak ve ark. (2018)'ın bildirdikleri denkleme göre hesaplanmıştır. $\mathrm{NYD}=[120 / \mathrm{NDF}] \times[88.9-(0.779 \times \mathrm{ADF})] \times[0.775]$.

Denemelerin sonuçları her bir lokasyon için ayrı ayrı olarak Tesadüf Blokları Deneme Deseni'ne göre değerlendirilmiştir (SAS, 1998). Yıl birleştirmesinde ise Çınar ve ark. (2014) tarafından açıklanan Tesadüf Bloklarında Zamanda Bölünmüş Parseller Deneme Desenine uygun olarak varyans analizi yapılmıştır. Ortalamalar arasında önemli farklılıkların ortaya çıktığı durumlarda, ortalamaları karşılaşstırmak için \% 5 ve \% 1 önemlilik düzeyinde LSD testi uygulanmıştır (Gülümser ve ark., 2006).

Kuru ot verimine ait stabilite analizi için SAS, 1998 programına ait proc REG modeli uygulanmıştır. Yonca çeşitlerinin kuru ot verimlerine ait stabilite parametreleri olarak ise ortalama verim $\left(\mathrm{X}_{\mathrm{ort}}\right)$, regresyon katsayısı $(\mathrm{b})$, regresyon sabitesi (a), belirtme katsayısı $\left(\mathrm{r}^{2}\right)$, varyasyon katsayısı $(\mathrm{VK})$ ve regresyondan sapma $\left(\mathrm{S}^{2} \mathrm{~d}\right)$ değerleri kullanılmıştır (Albayrak ve Yavuz, 2020).

\section{Bulgular ve Tartışma}

\subsection{Kuru ot verimi}

Varyans analiz sonuçlarına göre, hem Antalya hem de Samsun lokasyonunda yonca genotiplerinin kuru ot verimleri arasında \% 1 önem düzeyinde farklılıklar belirlenmiştir (Çizelge 2). Antalya lokasyonunda Aday çeşit (3243 kg da ${ }^{-1}$ ) ile Fortuna (3183 kg da-1), Samsun lokasyonunda ise Aday çeşit, Fortuna ve Nimet (sırasıyla, 2853, 2775 ve $2752 \mathrm{~kg} \mathrm{da}^{-1}$ ) en yüksek kuru ot verimleri vermişlerdir (Çizelge 3). Her iki lokasyonda da Golden West en düşük verimli çeşit olmuştur.

Yonca çok yıllık bir bitki olmasının yanı sıra yılda birden çok biçilmesinden dolayı elde edilen ot miktarı diğer yem bitkilerinden fazla olmaktadır. Elde edilen ot miktarında ise ekildiği bölgenin iklim şartları en önemli faktör olarak karşımıza çıkmaktadır. Yonca genotiplerinin kuru ot verimleri ekolojik koşullara ve biçim sayılarına bağlı olarak önemli varyasyonlar göstermektedir (Albayrak ve ark., 2018).

Çizelge 2. Varyans analiz sonuçları ve kareler ortalaması (2019-2020)

Table 2. Results of variance analysis and mean squares (2019-2020)

\begin{tabular}{|c|c|c|c|c|c|c|c|}
\hline $\begin{array}{c}\text { Varyasyon } \\
\text { Kaynakları }\end{array}$ & sd & KOV & HPO & ADF & NDF & ADL & NYD \\
\hline \multicolumn{8}{|c|}{ ANTALYA } \\
\hline Tekerrür & 3 & $28964 *$ & 0.387 & 0.345 & 1.689 & 0.194 & 43.14 \\
\hline Çeşit & 5 & $565567 * *$ & $5.78 *$ & $12.84 * *$ & 6.349 & $1.482 *$ & $255.00 * *$ \\
\hline Hata 1 & 15 & 6309 & 1.336 & 1.326 & 3.869 & 0.452 & 50.52 \\
\hline Y1l & 1 & $9427041 * *$ & 0.8001 & 3.630 & 1.190 & 0.662 & 85.33 \\
\hline Y1l x Çeşit & 5 & 15386 & 0.595 & 0.382 & 2.302 & 0.068 & 25.48 \\
\hline Hata 2 & 18 & 10140 & 1.612 & 0.951 & 2.148 & 0.464 & 35.79 \\
\hline \multicolumn{8}{|c|}{$\begin{array}{l}\text { SAMSUN } \\
\end{array}$} \\
\hline Tekerrür & 3 & 6702 & 0.601 & 1.137 & 0.513 & 0.462 & 18.07 \\
\hline Çeşit & 5 & $611841 * *$ & $10.06^{* *}$ & $13.72 *$ & 8.175 & $2.476^{* *}$ & $257.43^{*}$ \\
\hline Hata 1 & 15 & 9668 & 1.46 & 3.96 & 3.232 & 0.285 & 60.66 \\
\hline$Y_{11}$ & 1 & $460120 * *$ & 0.061 & $9.04 *$ & $10.193 *$ & 0.083 & $256.68 * *$ \\
\hline Y1l x Çeşit & 5 & 21408 & 0.788 & 0.54 & 0.361 & 0.133 & 4.637 \\
\hline Hata 2 & 18 & 8728 & 0.798 & 1.69 & 1.882 & 0.252 & 24.92 \\
\hline
\end{tabular}

sd: Serbestlik derecesi; $\quad * 0.05, * * 0.01$ düzeyinde önemlidir.

Yoncada kuru ot verimleri Karadeniz Bölgesi koşullarında 766-1456 kg da-1 (Töngel ve Ayan, 2010), Doğu Anadolu'da 604-2426 kg da ${ }^{-1}$ (Sabanc1 ve ark., 2013), Güney Doğu Anadolu'da 1594-2219 kg da ${ }^{-1}$ (Gülcan ve Anlarsal, 1992), Orta Anadolu'da 873-1205 kg da-1 (Altınok ve Karakaya, 2002), Akdeniz koşullarında 1467-1806 $\mathrm{kg} \mathrm{da}^{-1}$ (Avcı ve ark. 2010), Ege koşullarında 1102-1266 kg da-1 (Cevheri, 1998) ve 2031-2680 kg da-1 (Kavut ve Avcıoğlu 2015), Karadeniz iç geçit kuşağında 1131- $1518 \mathrm{~kg} \mathrm{da}^{-1}$ (Kır, 2010) ve Akdeniz iç geçit kuşağında 1480$1610 \mathrm{~kg} \mathrm{da}^{-1}$ (Albayrak ve Türk, 2013) arasında değişim gösterdiği farklı araştırıcılar tarafından bildirilmektedir. 
Farklı ülkelerde yapılan çalışmalarda; Cavero ve ark. (2017) yoncada ilk yıl dekara $1700 \mathrm{~kg}$ olan kuru ot veriminin ikinci yıl 2200 kg'a yükseldiğini bildirmişlerdir. Li ve Su (2017) yoncada kuru ot verimini 960-1354 kg $\mathrm{da}^{-1}$ aralığında bulmuştur. Garcia ve ark. (2017) $1335-2027 \mathrm{~kg} \mathrm{da}^{-1}$, Min (2016) 1554-1779 kg da-1 ve Jafarian ve ark. (2015) $750 \mathrm{~kg} \mathrm{da}^{-1}$ aralıklarında yoncada kuru ot verimini belirlemişlerdir. Hem Türkiye hem de farklı ülke şartlarında yapılan çalışmalarda görüldüğü üzere yoncanın kuru ot verimine çevre şartlarının etkisinin yüksek olduğu ayrıca kullanılan materyalin verim üzerine doğrudan etkili olduğu görülmektedir (Tucak ve ark., 2014).

Çizelge 3. Kuru ot verimi (KOV), ham protein oranı (HPO), Asit deterjan çözeltisinde çözünmeyen lif (ADF), Nötral deterjan çözeltisinde çözünmeyen lif (NDF), Asit deterjan çözeltisinden sonra kuvvetli asitte çözünmeyen lignin (ADL) ve Nispi yem değeri (NYD) ( 2 yılın ortalaması)

Table 3. Dry matter yield (DMY), crude protein (CP), acid detergent fiber (ADF), neutral detergent fiber (NDF), acid detergent lignin ( $A D L)$ and relative feed value (RFV) (average of 2 years).

\begin{tabular}{|c|c|c|c|c|c|c|}
\hline & $\begin{array}{c}\text { KOV } \\
\left(\mathrm{kg} \mathrm{da}^{-1}\right)\end{array}$ & $\begin{array}{c}\text { HPO } \\
(\%)\end{array}$ & $\begin{array}{r}\text { ADF } \\
(\%) \\
\end{array}$ & $\begin{array}{l}\text { NDF } \\
(\%)\end{array}$ & $\begin{array}{c}\text { ADL } \\
(\%)\end{array}$ & $\begin{array}{c}\text { NYD } \\
(\%)\end{array}$ \\
\hline \multicolumn{7}{|c|}{ ANTALYA } \\
\hline Aday & 3243 a & $21.87 \mathrm{a}$ & $28.71 \mathrm{~d}$ & 39.17 & $7.25 \mathrm{~b}$ & $158 \mathrm{a}$ \\
\hline Fortuna & 3183 a & $21.54 \mathrm{ab}$ & $29.01 \mathrm{~cd}$ & 39.63 & $7.52 \mathrm{~b}$ & $156 \mathrm{ab}$ \\
\hline Nimet & 3094 b & $21.64 \mathrm{ab}$ & $28.99 \mathrm{~cd}$ & 39.07 & $7.47 \mathrm{~b}$ & $158 \mathrm{a}$ \\
\hline Green star & $2853 \mathrm{c}$ & 20.51 bc & $30.19 \mathrm{cb}$ & 40.31 & $7.82 \mathrm{ab}$ & $151 \mathrm{ac}$ \\
\hline Isinde & $2780 \mathrm{c}$ & 20.59 bc & $31.24 \mathrm{ab}$ & 40.61 & $8.25 \mathrm{a}$ & 148 bc \\
\hline Golden west & $2557 \mathrm{~d}$ & $19.68 \mathrm{c}$ & $31.67 \mathrm{a}$ & 41.35 & $8.29 \mathrm{a}$ & $145 \mathrm{c}$ \\
\hline VK (\%) & 3.41 & 6.05 & 3.25 & 3.66 & 8.77 & 3.92 \\
\hline \multicolumn{7}{|c|}{ SAMSUN } \\
\hline Aday & $2853 \mathrm{a}$ & $21.03 \mathrm{a}$ & $29.44 \mathrm{~b}$ & 40.70 & $7.47 \mathrm{~b}$ & $151 \mathrm{a}$ \\
\hline Fortuna & $2775 \mathrm{a}$ & $19.97 \mathrm{ab}$ & $30.93 \mathrm{ab}$ & 41.31 & $7.60 \mathrm{~b}$ & $146 \mathrm{ab}$ \\
\hline Nimet & 2752 a & 20.77 a & $31.07 \mathrm{ab}$ & 41.73 & $7.79 \mathrm{~b}$ & $144 \mathrm{ac}$ \\
\hline Green star & $2396 \mathrm{~b}$ & 18.98 bc & $32.21 \mathrm{a}$ & 42.17 & $8.04 \mathrm{~b}$ & 141 bd \\
\hline Isinde & $2339 \mathrm{~b}$ & 18.79 bc & $32.46 \mathrm{a}$ & 43.01 & $8.75 \mathrm{a}$ & $138 \mathrm{~cd}$ \\
\hline Golden west & 2188 c & 18.29 c & $33.05 \mathrm{a}$ & 43.35 & $8.72 \mathrm{a}$ & $136 \mathrm{~d}$ \\
\hline VK (\%) & 3.66 & 4.55 & 4.13 & 3.26 & 6.23 & 3.50 \\
\hline
\end{tabular}

*Her bir sütunda aynı harfler ile gösterilen ortalamalar arasında $\mathrm{P}=0.05$ düzeyinde farklılık yoktur.

\subsection{Ham protein oranı}

Yonca genotiplerinin ham protein oranları arasında istatistiki olarak Antalya lokasyonunda \% 5, Samsun lokasyonunda ise \% 1 düzeyinde farklılık belirlenmiştir (Çizelge 2). Her iki lokasyonda da Aday çeşit ile birlikte Fortuna ve Nimet çeşitleri diğer yonca çeşitlerinden daha yüksek ham protein oranına sahip oldukları tespit edilmiştir (Çizelge 3).

Yonca hayvanlar için en ucuz ham protein kaynağıdır ve bitkinin protein içeriği gelişme dönemi ile doğrudan ilişkilidir (Radoviç ve ark. 2009). Farklı yonca çeşitleri ile farklı ekolojilerde yapılan çalışmalarda ham protein oranını; Albayrak ve Yavuz (2020) \% 21.79-18.22, Albayrak ve Öten (2020) \% 21.25-19.92, Kavut ve Avcioğlu (2015) \% 19.83-20.11, Kertikova ve ark., (2014) \% 17.28-24.36, Aioanei ve Pop (2013) \% 16.02-17.01, Çınar (2012) \% 20.60, Dale ve ark., (2012) \% 27.7, Muntianu ve ark., (2012) \% 15.47, Vintu ve ark., (2012) \% 21.17, Rimi ve ark., (2012) \% 18.50, Monirifar (2011) \% 21.31 arasında değiştiğini bildirmişlerdir. Araştırmamızda elde edilen ortalama ham protein oranları bazı araştırıcıların bildirdikleri sonuçlardan yüksek, bazılarınınkinden ise düşük olmuştur. Söz konusu farklılıkların ekolojik koşulların ve kullanılan materyal farklılıklarından kaynaklanabileceği söylenebilir (Albayrak ve ark., 2018).

\subsection{ADF oranı}

Yonca genotiplerinin ADF oranları arasında istatistiki olarak Antalya lokasyonunda \% 1, Samsun lokasyonunda ise \% 5 düzeyinde farklılık belirlenmiştir (Çizelge 2). Her iki lokasyonda da Aday çeşit ile birlikte Fortuna ve Nimet çeşitlerinin diğer çeşitlerden daha düşük ADF oranlarına sahip oldukları görülmüştür (Çizelge 3). Farklı yonca çeşitleri ile farklı ekolojilerde yapılan çalışmalarda ADF oranını; Aioanei ve Pop (2013) \% 30.56-34.78, Dale ve ark. (,2012) \% 31.89, Muntianu ve ark., (2012) \% 32.26, Rimi ve ark., (2012) \% 37.50, Homolka ve ark., (2008) \% 31.81, Holland ve Clive (2008) \% 28.00 olarak belirlemişlerdir. Araştırma bulgularımız yukarda belirtilen araştırmacıların sonuçlarıyla genel olarak benzerlik göstermektedir. Bununla birlikte yoncada kullanılan çeşit ve ekolojik faktörler ile birlikte hasat zamanındaki değişimlerinde otun ADF oranının değişmesinde en etkili faktör olduğu da belirtilmektedir (Rimi ve ark., 2012). 
Yonca genotipleri arasında NDF oranları bakımından her iki lokasyonda da istatistiki olarak farklılık bulunmamıştır (Çizelge 2). Bununla birlikte yonca genotiplerinin NDF oranları \% 43.35-39.17 aralığında değişim göstermiştir (Çizelge 3). Yoncada NDF oranını; Albayrak ve Yavuz (2020) \% 43.22-39.81, Albayrak ve Öten (2020) \% 40.88-38.24, Muntianu ve ark., (2012) \% 40.21, Rimi ve ark., (2012) \% 43.70, Homoka ve ark., (2008) \% 41.12, Holland ve Clive (2008) \% 37.00, Markoviç ve ark., (2007) \% 43.59, Yu ve ark., (2003) \% 46.90 olarak belirlemişlerdir. Araştırmamızda elde edilen ortalama NDF oranları bazı araştırıcıların bildirdikleri sonuçlardan yüksek, bazılarınınkinden ise düşük olmuştur. Söz konusu farklılıkların ekolojik koşulların ve kullanılan materyal farklılıklarından kaynaklanabileceği söylenebilir.

\subsection{ADL oranl}

Yonca genotiplerinin ADL oranları arasında istatistiki olarak Antalya lokasyonunda \% 5, Samsun lokasyonunda ise \% 1 düzeyinde farklılık belirlenmiştir (Çizelge 2). Her iki lokasyonda da Aday çeşit ile birlikte Fortuna ve Nimet çeşitlerinin diğer çeşitlerden daha düşük ADL oranlarına sahip oldukları görülmüsşür (Çizelge 3). Lignin bitkilerin kuvvetli olmasını sağlayan ve bitki vasküler sisteminin sızıntı olmaksızın bitki suyunu nakletmesini etkileyen selülozik yapı olarak bilinmektedir (Webb ve ark., 1996). Lignin, yoncada olgunlaşmaya bağlı olarak artmaktadır. Lignin ruminantlar da ne sindirim enzimleri ile ne de mikrobiyal enzimler ile sindirilemediği için yemlerin sindirilme derecelerini ve yemden yararlanmayı azaltmaktadır (Naser ve ark., 2011; Undersander ve ark., 2009). Ayrıca lignin; selüloz ve hemiselüloz gibi polisakkaritlerin sindiriminide olumsuz etkilemek suretiyle yemden yararlanmayı azaltmaktadır (Sridhar ve Senani, 2011). Yonca otunun sindirilebilirliğini azaltan en önemli bileşik lignindir (Webb ve ark., 1996). Lignin oranının \% 6.5-8.4 aralığından yüksek olması yonca otunun kalitesini doğrudan etkilediği ve yetiştirme döneminde yüksek sıcaklıklar bitkide lignin oranının artmasına neden olduğu bildirilmektedir (Shewmaker ve ark., 2009). Yoncada lignin oranının belirlenmesi için yapılan çalışmalarda; Malushi ve ark., (2017) \% 7.4, Sulc ve ark., (2017) \% 4.0-5.0, Boziskoviç ve ark., (2014) \% 6.21, Kertikova ve ark. (2014) \% 4.62-7.32, Yari ve ark., (2014) \% 7.1-7.8 oranlarında lignin içerikleri belirlenmiştir. Araştırma bulgularımız yonca genotiplerinin ADL oranlarının makul sınırlar içerisinde olduğunu göstermektedir.

\subsection{Nispi yem dĕgeri}

Yonca genotiplerinin NYD oranları arasında istatistiki olarak Antalya lokasyonunda \% 1, Samsun lokasyonunda ise \% 5 düzeyinde farklılık belirlenmiştir (Çizelge 2). Antalya lokasyonunda çeşitlerini NYD oranları \% 145-158, Samsun lokasyonunda ise \% 136-151 aralığında değişim göstermiştir (Çizelge 3).

Kaliteli yonca otunda NYD 120-190 aralığındadır (Putman, 2010). Yonca otunun NYD 180'den büyük ise en üstün, 150-180 aralığında üstün, 125-150 aralığında iyi, 100-120 aralığında orta ve 100'den az ise düşük kaliteli sınıfa girdiği belirtilmiştir (Albayrak ve Öten, 2020). Araştırmamızda yer alan yonca genotipleri en üstün ve üstün gurupta yer almışlardır.

\subsection{Stabilite analizi}

Stabilite analizinde; ortalama verim ( $\mathrm{X}_{\text {ort }}$ ) tüm çeşitlerin ortalamasında yüksek olan, Regrasyon katsayısı (b) 1'e yakın, regrasyon sabitesi (a) pozitif, belirtme katsayısı $\left(\mathrm{r}^{2}\right)$ yüksek, varyasyon katsayısı ve regrasyondan sapma $\left(\mathrm{S}^{2}\right.$ d) değeri düşük olan çeşitler stabil olarak kabul edilir (Albayrak ve ark., 2005). Buna göre; Aday yonca çeşidi; en yüksek ortama kuru ot verimine sahip olup, b değeri (1.06), a değeri (116.32) pozitif, $\mathrm{r}^{2}$ yüksek VK ve $\mathrm{s}^{2} \mathrm{~d}$ değeri düşük olmasından dolayı diğer çeşitlere göre daha stabil olduğu belirlenmiştir (Çizelge 4. Şekil 1).

Çizelge 4. Yonca çeşitlerinin toplam kuru ot verimi için stabilite parametrelerine ilişkin değerler Table 4. Values related to stability parameters of alfalfa cultivars for total dry matter yield

\begin{tabular}{lcccccc}
\hline Çeşitler & $\mathrm{X}_{\text {ort }}$ & $\mathrm{b}$ & $\mathrm{a}$ & $\mathrm{r}^{2}$ & $\mathrm{CV}$ & $\mathrm{S}^{2} \mathrm{~d}$ \\
\hline Aday & 3048 & 1.06 & 116.32 & 0.99 & 1.02 & 966 \\
Fortuna & 2979 & 0.98 & 277.54 & 0.98 & 2.84 & 7170 \\
Nimet & 2923 & 0.93 & 353.76 & 0.97 & 3.36 & 9631 \\
Green star & 2625 & 0.98 & -66.57 & 0.99 & 1.75 & 2632 \\
Isinde & 2559 & 1.08 & -419.07 & 0.99 & 0.28 & 54.04 \\
Golden West & 2372 & 0.93 & -200.14 & 0.99 & 0.54 & 164 \\
\hline
\end{tabular}




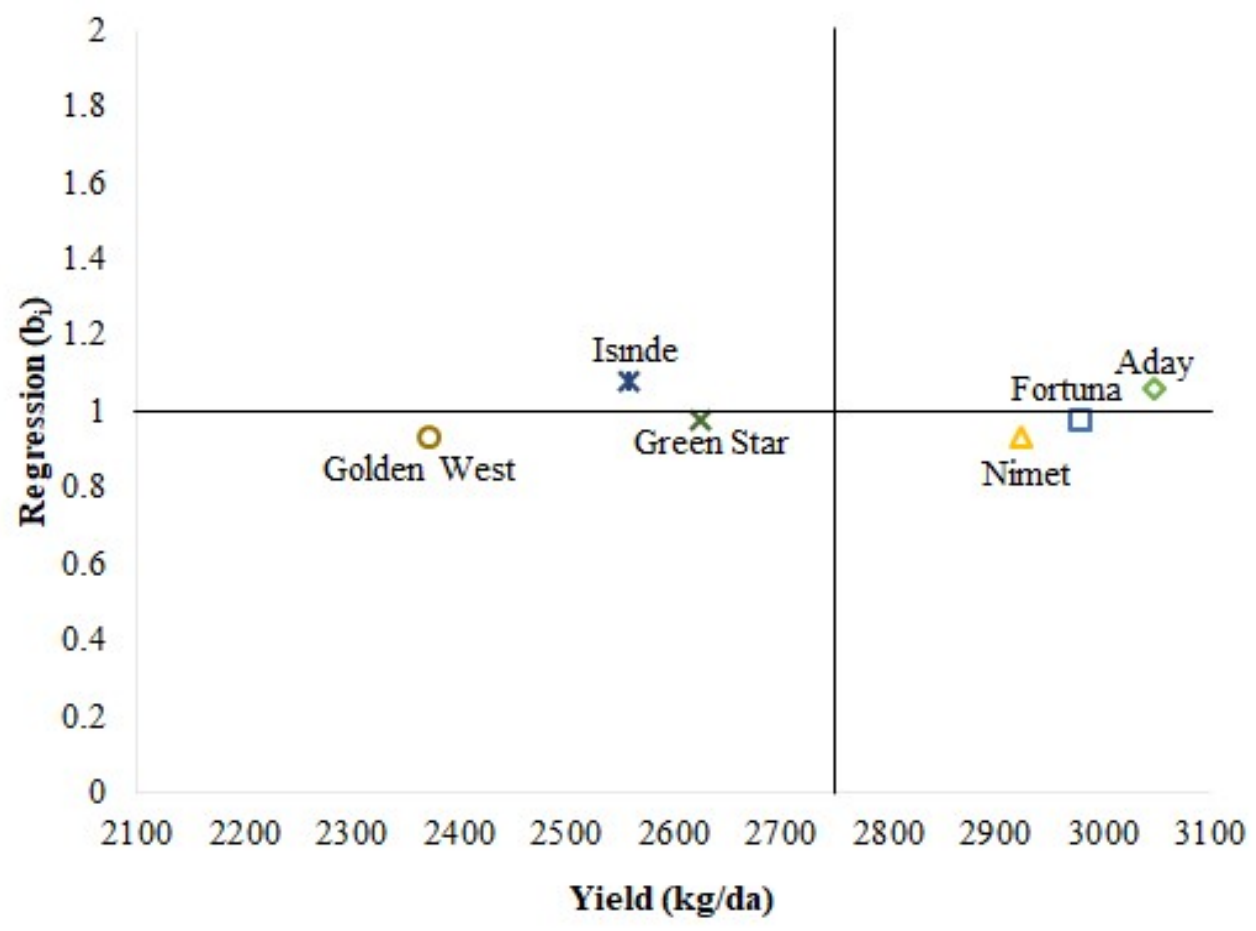

Şekil 1. Kuru ot verimi ve regresyon katsayısına göre yonca çeşitlerinin stabilite durumları.

Figure 1. Stability statues of alfalfa cultivars according to dry matter yield and regression coefficient.

\section{Sonuç}

Araştırmadan elde edilen sonuçlara göre, Aday çeşit, Fortuna ve Nimet çeşitleri ile birlikte hem Antalya hem de Samsun lokasyonunda en yüksek kuru ot verimine sahip olmuşlardır. Benzer şekilde aynı çeşitler ham protein oranı bakımından da diğer çeşitlerden üstünlük göstermişlerdir. Yonca otunun sindirilebilirliğinin ölçüsü olan ADF, NDF ve ADL içerikleri bakımından her iki lokasyonda da Golden West çeşidi diğer çeşitlerden daha yüksek değere sahip olmuştur. Araştırmamızda yer alan tüm çeşitler nispi yem değeri bakımından en üstün ve üstün gurupta yer almışlardır. Stabilite analizi sonuçlarına göre Aday çeşidin diğer çeşitlerden kuru ot verimi bakımından daha stabil olduğu belirlenmiştir. Sonuç olarak; yaklaşık 10-12 yıllık bir sslah programının sonucu olarak geliştirilmiş ve nondormant özelliğe sahip yoncanın 2021 yılı içerisinde "T.C. Tarım ve Orman Bakanlığı Tohumluk Tescil ve Sertifikasyon Müdürlüğü’ne tescil için başvuru yapılmasına karar verilmiştir.

\section{Kaynaklar}

Aioanei, N.M., Pop, I.M. 2013. Research on chemical composition of alfalfa hay obtained in different production systems (Conventional and Organic). University of Agricultural Sciences and Veterinary Medicine. 60: 60-64.

Albayrak, S., Öten, M. 2020. Döl kontrolü parsellerindeki yonca (Medicago sativa L.) genotiplerinin verim ve kalite özellikleri ile genel kombinasyon yeteneklerinin belirlenmesi. Anadolu Tarım Bilim. Dergisi. 20(3): 353-360.

Albayrak, S., Yavuz, T. 2020. Yield and quality characteristics of alfalfa (Medicago sativa L.) cultivars. Turkish Journal of Range and Forage Science (TJRFS), 2020, 1(1): 1 - 6

Albayrak, S., Türk, M., Sevimay, C.S., Öten, M., 2018. Türkiye'nin iç ve sahil bölgelerine uygun yerli yonca sslahı. TUBITAK Proje No: 2140066 Sonuç raporu.

Albayrak, S., Öten, M., Türk, M., Alagöz, M. 2018. An investigation on improved source population for the alfalfa (Medicago sativa L.) breeding. Legume Research. 41(6): 828-832.

Albayrak, S., Türk, M., 2013. Changes in the forage yield and quality of legume-grass mixtures throughout the vegetation period. Turk J. Agriculture and Forestry. 17(2): 139-147.

Albayrak, S., Töngel, M.Ö., Güler, M. 2005. Orta Karadeniz bölgesinde çeşit adayı fiğ (Vicia sativa L.)'lerin verim öğelerinin belirlenmesi ve stabilite analizi. OMU. Ziraat Fakültesi Dergisi. 20(1): 50-55.

Altınok, S., Karakaya, A., 2002. Forage yield of different alfalfa cultivars under Ankara conditions., Tr.J. of Agric. For., (26) s: 11-16.

Anonim, 2021. www. ankom.com. 
Avcı, M., Çınar, S., Yücel, C., İnal, İ. 2010. Evaluation of some selected alfalfa (Medicago sativa L.) lines for herbage yield and forage quality. Journal of Food, Agriculture \& Environment Vol.8 (3\&4) : 545-549.

Boziskoviç, A.D., Grubiç, G.A., Dordeviç, N.Z., Stojanoviç, B. D. 2014. Changes in alfalfa cell wall structure during vegetation. Journal of Agricultural Sciences. 59(3): 275-286.

Brummer, E.C., Shah, M.M., Luth, D. 2000. Reexamining the relationship between fall dormancy and winter hardiness in alfalfa. Crop Sci., 40: 971-978.

Cavero, J., Faci, J.M., Medina, E.T., Martínez-Cob, A. 2017. Alfalfa forage production under solid-set sprinkler irrigation in a semiarid climate, Agricultural Water Management , 191: 184-192.

Chen, J.S., Zhu, R.F., Zhang, Y.X., Cao, G., Di, G.L. 2014. Yields of alfalfa varieties with different fall dormancy levels in northeast China. Pak. J. Bot., 46(1): 167-172.

Çınar, S., Hatiboğlu, R., Gündel, F.D., Aktaş, A., Kılıçalp, N. 2014. Akdeniz iklim kuşağında bazı çok yıllık sıcak mevsim buğdaygil yem bitkilerinin yonca ile karışımlarının performanslarının belirlenmesi, TUBİTAK Proje No: 1100695 Sonuç raporu.

Çınar, S. 2012. Çukurova taban koşullarında bazı çokyıllık sıcak mevsim buğdaygil yembitkilerinin yonca (Medicago sativa L.) ile uygun karışımlarının belirlenmesi, Çukurova Üniversitesi, Fen Bilimleri Enstitüsü (Doktora tezi), 151s, Adana.

Cevheri, A.C. 1998. Investigations on the yield and other yield characteristics of 11 different alfalfa varieties under Bornova conditions. MSc Thesis. Ege University, Institute of Science, İzmir.

Dale, L.M., I. Rotar., A. Thewis., R.Vidican., V. Florian., A. Ciure. 2012. Determination of alfalfa crude fiber, NDF, ADF and lignin content by NIR spectrometry. Agronomie. 5: 245-249.

Dhont, C., Castonguay, Y., Nadeau, P., Belanger, G., Chalifour, F.P. 2002. Alfalfa root carbohydrates and regrowth potential in response to fall harvests. Crop Sci., 42: 754-765.

Djaman, K., O’Neill, M.K., Koudahe, K. 2020. Evaluation of different fall dormancy rating alfalfa cultivars for forage yield in a semiarid environment. Agronomy. 10(1): https://doi.org/10.3390/agronomy10010146

Fairey, D.T., Lefkovitch, L.P., Fairey, N.A. 1996. The relationship between fall dormancy and germplasm source in North American alfalfa cultivars. Can. J. Plant Sci., 76:429-432.

Garcia, R., Adelaido. R., Nicolas, T.S. Santiago, J.C. 2017. Yield components of alfalfa (Medicago sativa L.) varieties. Agrociencia. 57(7): 697-708.

Gülcan, H., Anlarsal, A. E. 1992, GAP Bölgesinde sulu koşullarında yetişebilecek yonca çeşitlerinin saptanması üzerinde araştırmalar, Ç.Ü.Z.F. Genel Yay. No:32, GAP Yay. No: 61, Adana.

Gülümser, A., Bozoğlu, H., Pekşen, E., 2006. Araştırma ve Deneme Metotları. Ondokuz Mayıs Üniversitesi, Ziraat Fakültesi, Ders Kitabı no: 48. (2. Bask1).

Haagenson, D.M., Cunningham, S.M., Joern, B.C., Volenec, J.J. 2003. Autumn defoliation effects on alfalfa winter survival, root physiology, and gene expression. CropSci., 43: 1340-1348.

Holland, T., Clive Wes, K. 2008 -Alfalfa Hay Management, Western Beef Resource Committee, Library Range and Pasture Section (pp.580-1 - 580-4). The CSU Beef Group.

Homolka, P., V. Koukolova., Z. Nemec., Z. Mudrik., B. Hucko., J. Sales. 2008. Amino acid contents and intestinal digestibility of lucerne in ruminants as influenced by growth stage. Czech Journal of Animal Science. 499-505.

Jafarian, S., Chaichi, M.R., Ghahderijani, M.M.2015. Effects of surfactant and limited irrigation on forage yield and quality of alfalfa (Medicago sativa L.), Australian J. of Crop Science, 10(1):76-80.

Kacar, B., İnal, A., 2008. Bitki Analizleri. Nobel yayınları. No: 1241, Ankara, 892 s.

Kavut, Y.T., Avcioğlu, R. 2015. Yield and quality performances of various alfalfa (Medicago sativa L.) cultivars in different soil textures in a mediterranean environment, Turkish Journal of Field Crops, 20(1): 65-71.

Kertikova, D., Naydenova, Y., Yankov, D. 2014. Evaluation of the productivity and quality of elite alfalfa clones. Agrarni Nauki. 6 (16): 25-31.

Kır, H. 2010. Tokat-Kazova şartlarında bazı yonca çeşitlerinin performanslarının belirlenmesi, Gaziosmanpaşa Üniversitesi, Fen Bilimleri Enstitüsü (Yüksek Lisans tezi), 44s, Tokat.

Li, Y., Su, D. 2017. Alfalfa water use and yield under different sprinkler irrigation regimes in north arid Regions of China. Sustainability 2017, 9: 1380, 1-1.

Malinowski, D.P., Pinchak, W.E., Kramp, B.A., Zuo, H., Butler, T.J. 2007. Supplemental irrigation and fall dormancy effects on alfalfa productivity in a semiarid, subtropical climate with a bimodal precipitation pattern. Agron. J., 99:621-629.

Malushi, N., Papa, L., Maia, M., Oliveira, H., 2017. Determination of chemical content and dry matter digestibility of some under-utilized feeds in ruminants feeding through two in vitro methods. Scientific Papers. Series D. Animal Science. Vol. LX: 91-96.

Markovıç, J., Radovıç, J., Lugıç, Z., Sokolovıç, D. 2007 - The effect of development stage on chemical composition of alfalfa leaf and stem,Biotechnology in Animal Husbandry, 23 (5-6), 383 -388. 
Min, D., 2016. Effects of cutting interval between harvests on dry matter yield and nutritive value in alfalfa. American Journal of Plant Sciences. 7: 1226-1231.

Monirifar, H. 2011. Path analysis of yield and quality traits in alfalfa. Not Bot Horti Agrobo, 39(2):190-195.

Muntianu, I.C., Vîntu, V., Samuil, C., Albu, A., Stavarache, M., Ciobanu, C. 2012. The chemical composition of the forage from a cultivated meadow of alfalfa and orchard grass. Lucrări Ştiinţifice - Seria Zootehnie,58: 35-40.

Naser M., Bayaz A., Ramin S., Alireza A., Abolfazı A., Mehdi M., 2011. Determining nutritive value of soybean straw for ruminants using nylon bags technique. Pak. J. Nutr., 10, 838-841.

Putman, D., 2010. Changing forage quality testing for alfalfa hay markets, California Alfalfa \& Forage Symposium, Visalia, CA, Nov. 30-Dec 2, 2010, USA.

Radoviç, J., Sokoloviç, D., Markoviç, J., 2009. Alfalfa-most important perennial forage legume in animal husbandry. Biotechnology in Animal Husbandry. 25: 465-475.

Rimi, F., Macolino, S., Leinauer, B., Lauriault, L.M., Ziliotto, U., 2012. Fall dormancy and harvest stage effects on alfalfa nutritive value in a subtropical climate. Agron. J. 104: 415-422.

Russelle, M.P., Lamb, J.F.S., Turyk, N.B., Shaw, B.H., Pearson, B. 2007. Managing nitrogen contaminated soils. Agron. J. 99: 738-746.

Sabanc1, C.O., Ertuş, M., Çelebi, S.Z. 2013. Collection, conservation and evaluation for forage yield of alfalfa landraces grown in East Anatolia. Turkish Journal of Field Crops, 18(1), 46-51.

SAS Institute. 1998. INC SAS/STAT users' guide release 7.0, Cary, NC, USA.

Sridhar M., Senani S., 2011. Lignin in lignocellulosics - a boon or a bane for ruminants. Everyman's Science, 66, 227-232.

Shewmaker, G.E., Chahine, M., Wilson, R., 2009. Parameters for good quality alfalfa hay. Idaho Alfalfa Forage and Forage Conferance, 3-4 February, 6-10. USA.

Sulc, R.M., Parker, A., Albrecht, K., Cassida, K., Hall, M., Min, D., Orloff, S., Xu, X., Undersander, D. 2017. Agronomic and nutritional attributes of reduced lignin alfalfa, Tri-State Nurtition Conference. April 17-19; 7987.

Töngel, M.Ö., Ayan, İ. 2010. Nutritional contenst and yield performances of lucerne (Medicago sativa L.) cultivars in Southern Black Sea Shores, Journal of Animal and Veterinary Advances. 9: 2067-2073.

Tucak, M., Popovıç, S., Čupıç, T., Krızmanıç, G., Šımıç, B., Meglıç, V. 2014. Agromorphological and forage quality traits of selected alfalfa populations and their application in breeding, Turkish Journal of Field Crops, 19(1): 79-83.

Undersander, D., McCaslin, M., Sheaffer, C. Whalen, D., Miller, D., Putnam, D., Orloff, S. 2009. Low lignin alfalfa: redefining the yield/quality tradefoff. Western Alfalfa \& Forage Conference, December 2-4, 2009, Reno, Nevada.

Vintu, V., Stavarache, M., Samuil, C., Muntean, I. 2012. Chemical composition dynamics of alfalfa (Medicago sativa L.) at different plant growth stages. EGF 2012, Grasland Science in Europe, 17, 394-396.

Webb, D. H., Nutter, F. W., Jr., Buxton, D. R. 1996. Effect of acid detergent lignin concentration in alfalfa leaves on three components of resistance to alfalfa rust. Plant Dis. 80: 1184-1188.

Yari, M., Valizadeh, R., Naserian, A.A., Jonker, A., Azarfar, A., Yu, P. 2014. Effects of including alfalfa hay cut in the afternoon or morning at three stages of maturity in high concentraterations on dairy cows performance, diet digestibility andfeeding behavior. Animal Feed Science and Technology 192 (2014) 62-72.

Yu, P., Christensen, D. A., Mckinnon, J. J., Markert, J. D. 2003. Effect of variety and maturity stage on chemical composition, carbohydrate and protein subfractions, in vitro rumen degradability and crude energys of timothy and alfalfa. Canadian Journal of Animal Science, 279-290. 